\title{
Adventitious root initiation in adult and juvenile cuttings of Guindilia trinervis, an endemic plant of Chile suitable for biodiesel production
}

\author{
Iniciación adventicia de raíces en estacas adultas y juveniles de Guindilia trinervis, \\ una planta endémica de Chile, apta para producción de biodiésel

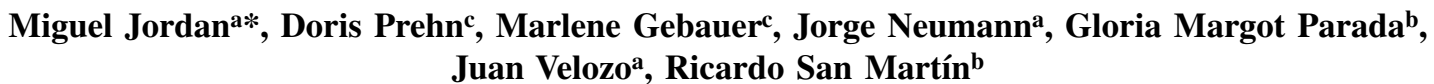 \\ *Corresponding author: aniversidad Mayor, Instituto de Biotecnología, Campus Huechuraba, Santiago, Chile, \\ tel.: 56-2-3281000 anexo 5012, fax: 56-2-3281351, miguel.jordan@umayor.cl, mjordanz@gmail.com \\ bPontificia Universidad Católica de Chile, Facultad de Ingeniería, Departamento de Ingeniería Química \\ y Bioprocesos, Laboratorio de Biocombustibles y Biopesticidas, Santiago, Chile. \\ 'Pontificia Universidad Católica de Chile, Facultad de Agronomía e Ingeniería Forestal, Santiago, Chile.
}

\begin{abstract}
SUMMARY
Guindilia trinervis is a native Chilean shrub that bears seeds with a high content of oil suitable for biodiesel production. It was tested for its capacity to form roots in cuttings of juvenile and adult plants in ex vitro as well as in vitro conditions. Variables such as type of cutting, exogenous application of IBA $^{1}$ and time of collection were studied. For adult plants, the best ex vitro rooting (79\%) was obtained with distal polynodal cuttings collected in late summer and treated with $100 \mathrm{mg} \mathrm{L}^{-1}$ IBA, but rooting was also achieved in the presence of water alone (up to $69 \%$ ). Juvenile plants displayed the best rooting $(84 \%)$ with single node cuttings and 50 mg $\mathrm{L}^{-1}$ IBA, as well as in the presence of Seradix $(72 \%)$. This treatment also showed the highest number of roots per explant. In vitro rooting of shoot tips took place on modified MS media supplemented with $1.0 \mathrm{mg} \mathrm{L} \mathrm{L}^{-1}$ IBA yielding roots up to $82 \%$, compared to nodal sections that rooted scantily. Rooted material could be acclimated and adapted well to greenhouse and nursery conditions. Controls of adult and juvenile cuttings treated with water exhibited spontaneous rooting in most of the treatments. Cuttings from adult plants harvested in late summer rooted better than those harvested in winter. Spring cuttings collected during flowering and fructification did not root. Results indicate that by means of adventitious root initiation G. trinervis can be effectively propagated by distal cuttings, collected in summer or winter. This may allow large-scale production of plant material with desired traits.
\end{abstract}

Key words: adventitious root initiation, Guindilia trinervis, cuttings.

\section{RESUMEN}

Guindilia trinervis es un arbusto silvestre nativo de Chile productor de semillas con alto contenido de aceite y aptitudes para producción de biodiésel. En este estudio se investigó la capacidad de propagar vegetativamente esta especie evaluando el enraizamiento de estacas de plantas juveniles y adultas. Las variables estudiadas fueron el tipo de estaca, niveles exógenos de IBA ${ }^{2}$ y la época de colecta. Para plantas adultas el mejor enraizamiento (79\%) ocurrió en estacas polinodales (distales) colectadas a fines de verano y tratadas con $100 \mathrm{mg} \mathrm{L}^{-1}$ de IBA, y en presencia de agua sola (hasta 69\%). En plantas juveniles el mejor enraizamiento (84\%) ocurrió en estacas uninodales con $50 \mathrm{mg} \mathrm{L}^{-1}$ de IBA y también con Seradix (72\%); este tratamiento indujo el máximo número de raíces por explante. Ápices provenientes de plantas juveniles cultivados in vitro enraizaron hasta un $82 \%$, en medio MS modificado, suplementado con $1.0 \mathrm{mg} \mathrm{L}^{-1}$ de IBA. Las secciones nodales enraizaron escasamente. Las plántulas de todos los tratamientos se aclimataron y adaptaron bien en invernadero y vivero. El control con agua en estacas adultas y juveniles originó raíces en casi todos los ensayos. En verano las respuestas rizogénicas fueron superiores que en invierno. Las estacas colectadas en época de floración o fructificación no enraizaron. Los resultados indican que $G$. trinervis puede ser propagada en forma eficiente mediante la inducción de raíces adventicias preferentemente en estacas distales colectadas a fines de verano. Esta respuesta permitiría la propagación de plantas con caracteres deseados en programas de producción masiva.

Palabras clave: iniciación adventicia raíces, Guindilia trinervis, estacas.

IBA: indole-3-butyric acid; MS: Murashige and Skoog; WP: wet powder.

IBA: ácido indol butírico; MS: Murashige y Skoog; WP: polvo mojable. 


\section{INTRODUCTION}

Guindilia trinervis Gillies ex Hook. et Arn. (Sapindaceae), common name guindilla, is a Chilean native evergreen shrub, slightly known botanically (Ferrucci 1998, Hoffmann 1998, Riedemann and Aldunate 2004, Teillier et al. 2005, Riedemann et al. 2008). It has been described as suitable for biodiesel production, due to the $65-70 \%$ oil content of the seeds (Aguilera et al. 1986). Oil yields of approximately 500-600 $\mathrm{L} \mathrm{ha}^{-1}$ have been estimated, as well as an adequate chemical composition for biodiesel conversion (Seigler et al. 1987). In Central Chile, G. trinervis (figure 1A) is mainly found on sunny, north-facing slopes, on rocky and thin soils (Iglesias and Taha 2010). It grows predominantly at altitudes of 1,400-2,200 m a.s.l. in the Mediterranean sub Andean sclerophyll forest (Muñoz et al. 2000). This condition, together with its natural distribution in nonagricultural lands, makes $G$. trinervis not competitive for food crops, even if it is palatable to cattle in the wild. So far, no selection or multiplications have been completed on this species and only little botanical characterization work is available. On a same site, plants display considerable variability in height, morphology, seed biomass production and tolerance to the obligate parasite Cuscuta chilensis Ker Gawl. This variability may be attributed to genotype differences due to heterozygosis capacity of seeds and sexual propagation. In our observations $G$. trinervis displays floral polymorphism with predominant pistils that suggests out-crossing, a feature that is common to other members of this family (Bawa, 1977). Limited pollination and restrictive abiotic resources can also cause variations in the reproductive output, as described for Chuquiraga oppositifolia D. Don., a species that cohabits with $G$. trinervis (Muñoz and Arroyo 2006). However, in spite of the high variability present in the field, homogeneous patches of plants are also observed. In these cases the expansion of plants occurs by underground stem growth, or tuberous stems (Hartmann et al. 2001). Plants in the wild can therefore be from sexual or asexual origin. Exploitation of the genetic potential of superior plants through vegetative propagation has been achieved in many woody species (Ahuja and Libby 1993) and should provide a valuable tool for domesticating $G$. trinervis. If large-scale production of more fruitful plants with desirable attributes is feasible, traits may be fixed via asexual reproduction. The objective of this study was to evaluate the plasticity of $G$. trinervis to form roots in different type of cuttings derived from adult and juvenile plants throughout the seasons and to explore its ability to root in vitro and ex vitro.

\section{METHODS}

Ex vitro experiment for rooting of adult stem cuttings. Adult material was excised from selected wild plants in a field located close to Santiago de Chile (33²0.180' S; $\left.70^{\circ} 19.614^{\prime} \mathrm{W}\right)$ at an altitude of $1,750 \mathrm{~m}$ a.s.l. Selection criteria of donor plants were based on seed yield and aerial biomass increase. Plants were homogeneous in appearance and situated in close vicinity. All explants were excised from six to seven donor plants (approx. $1.0 \mathrm{~m}$ height); experimental material was pooled and randomly assigned to trials. Cuttings from adult plants were harvested in three seasons: (1) in late summer after fruit shedding (February), (2) during winter (June), and (3) in spring (October). Three types of explants were used from the adult material: (1) polynodal cuttings bearing 3-4 axillary buds obtained from the apical (distal) portion of the branch, (2) polynodal cuttings also with 3-4 axillary buds from the basal (proximal) portion of the branch (both nearly $10 \mathrm{~cm}$ long), and (3) single-node cuttings excised from the middle portion. Cuttings were treated with IBA in aqueous solutions $(100,200,400,800$, and 1,200 mg $\left.\mathrm{L}^{-1}\right)$ and wet powder (WP) formulations $(0.2,0.4,0.8$, and $1.2 \%)$. WP formulations were prepared by dissolving IBA in $96 \%$ alcohol, mixing the solution with talcum powder ( $\%$ w/w) and drying the mixture at $30{ }^{\circ} \mathrm{C}$ during $24 \mathrm{~h}$. Rooting was evaluated after six weeks in summer material and eight weeks in winter material.

Ex vitro experiment for rooting of juvenile stem cuttings. Juvenile plants, derived from seeds, were grown in a greenhouse for six months and cuttings were harvested in winter (June). Cuttings consisted in shoot tips as well as single sub-apical node explants, nearly $4 \mathrm{~cm}$ in size. All explants had at least two leaves that were not removed. The treatments included different auxin formulations: (1) Seradix $®$ powder $[0.3 \% \mathrm{w} / \mathrm{w}$ IBA], (2) IBA dissolved in warm lanolin [0.5 mg IBA per g lanolin], (3) IBA in aqueous solution [50 $\left.\mathrm{mg} \mathrm{L}^{-1}\right]$. Incubation in tap water was used as a control. Evaluations were carried out after six weeks of culture.

In both experiments solutions were prepared by dissolving IBA in a few drops of alcohol and completing the required volume with distilled water. Treatments with aqueous solutions of IBA or tab water were completed by dipping the base $(1-2 \mathrm{~cm})$ of adult and juvenile cuttings for $15 \mathrm{~min}$ in the liquid. Either WP formulations or lanolin was applied by slightly dunking in the base and verifying adherence of the substance. In the case of WP formulation the base was moistened with $50 \%$ ethanol prior to the treatment. Thereafter, the explants were set into a wet autoclaved substrate composed of $20 \%$ peat moss, $20 \%$ sand, and $60 \%$ perlite. Juvenile cuttings were cultured in plastic boxes covered with lids that were gradually removed as sprouting occurred. Adult cuttings were cultured in mist propagating beds and after rooting, each plant was transferred into a $1 \mathrm{~L}$ plastic bag. Experiments were conducted in the greenhouse and consisted of 24 cuttings per treatment for juvenile material and 40 cuttings for adult material. Trials were replicated three times. Temperatures in the greenhouse were kept in a range of $22-25{ }^{\circ} \mathrm{C}$ and relative humidity was maintained above $70 \%$. Light was 
supplemented with $400 \mathrm{~W}$ sodium lamps to simulate a $16 / 8$ photoperiod during winter trials.

The parameters that were examined for propagation of G. trinervis comprised: cutting length (polynodal as well as single node explants), position in the branch (distal vs. proximal), IBA levels/formulations, season and plant age (explants from adult plants in the field vs. six month-old juvenile plants).

In vitro experiments for rooting of shoot-tip and nodal cultures. Explants (about $2 \mathrm{~cm}$ in size) for in vitro shoottip and nodal sections were excised from plants that were originated from seeds and grown in a greenhouse during six months. Both types of explants were washed and surface disinfected for 15 min under constant agitation in fungicide solution $\left(3.5 \mathrm{~g} \mathrm{~L}^{-1}\right.$ Captan [13\%] and $2.5 \mathrm{~g}$ $\mathrm{L}^{-1}$ Benlate $\left.{ }^{\circledR}\right)$, incubated $8 \mathrm{~min}$ in $1.25 \% \mathrm{NaOCl}(25 \%$ commercial bleach Clorox $\left.{ }^{\circledR}\right)$, and rinsed three times in sterile distilled water. Cultures were performed in $25 \times 130$ $\mathrm{mm}$ tubes containing $12.5 \mathrm{ml}$ nutrient solution at $\mathrm{pH} 5.8$, solidified with $2.5 \mathrm{~g} \mathrm{~L}^{-1}$ Gellan Gum (PhytoTechnology G434) plus $3.5 \mathrm{~g} \mathrm{~L}^{-1}$ Agar (PhytoTechnology A1111). Tubes containing the culture media were covered with aluminum foil and autoclaved for $20 \mathrm{~min}$ at $121{ }^{\circ} \mathrm{C}$ and $75.842 \mathrm{kPa}$ (11 psi). Culture conditions in the growth chamber were $25 \pm 4{ }^{\circ} \mathrm{C}$, photoperiod 16/8, and photon flux $82 \mu \mathrm{mol}$ $\mathrm{m}^{-2} \mathrm{~s}^{-1}$ (Quantium Meter, QMSW-SS).

Rooting experiments included three nutrient media based on MS salts and vitamins (PhytoTechnology M519). Treatments were: (1) T1: 1/2 strength nutrients, sucrose $10 \mathrm{~g}$ $\mathrm{L}^{-1}$; (2) $\mathrm{T} 2: 1 / 2$ strength nutrients, sucrose $5 \mathrm{~g} \mathrm{~L}^{-1}$; and (3) T3: $1 / 4$ strength nutrients, sucrose $5 \mathrm{~g} \mathrm{~L}^{-1}$. All treatments were supplemented with $1 \mathrm{mg} \mathrm{L}^{-1}$ IBA. Plantlets in T1 were sub-cultured after 30 days and rooting response was assessed. Treatments T2 and T3 were evaluated after 30 days and rooted plantlets were acclimated in the growth chamber. Acclimation took place in transparent plastic containers filled $1 / 3$ with peat substrate. Thereafter plants were relocated to the greenhouse, in the same conditions as described for juvenile and adult cuttings.

Statistical analyses. Differences in responses were evaluated with [Stats ${ }^{\mathrm{TM}}$ ], by "comparison of proportions test" (Kohan and Carro 1970). The juvenile rooting assay used 24 explants per treatment (four treatments) and was repeated three times. The experiment for rooting adult cuttings consisted of 120 explants per treatment (10 treatments) and was also repeated three times. In vitro rooting trials were unbalanced with a variable number of explants per treatment.

\section{RESULTS}

Rooting of adult stem cuttings. Cuttings excised during late summer from adult field plants rooted profusely (table 1). Rhizogenesis took place in all IBA treatments, and water controls also showed root formation in 50-70\% of the explants (figure 1B). Rooting was more efficient at relatively lower IBA levels. The best response was obtained with distal cuttings harvested in summer, where approximately $80 \%$ of root formation took place in the presence of $100 \mathrm{mg} \mathrm{L}^{-1}$ IBA (table 1). IBA was equally successful when applied in the form of aqueous solution or powder. Control roots were usually thinner and longer than those of IBA treatments; indeed, the latter were more fragile and broke easily when handled. Higher IBA levels increased the number of roots per cutting in both polynodal distal and proximal cuttings. Proximal cuttings exhibited a good response, although slightly lower than distal cuttings. Both types appeared more suitable than single-node cuttings since axillary bud development of up to $98 \%$ occurred along rooting (table 1 ). Single node cuttings kept their green leaves and expressed some sprouting, but apical shoot growth stopped during the whole rooting period. Callus formation was commonly found in all explants regardless of the treatment. Callus size was small and did not interfere with root emergence. Moreover, adventitious roots had vascular connection to the cutting and did not originate from the callus.

Cuttings excised entering winter showed a lower rooting potential compared to those collected in summer (table 2). On average, explants rooted less (11\% winter vs. $38 \%$ summer), had a lower root number per explant (2.2 vs. 5.2) and fewer sprouts (11\% vs. $43 \%$ ) (tables 1 and 2). During winter, all types of cuttings treated with WP formulations, or IBA in aqueous solutions, did not exhibit clear rooting differences (table 2). The effect of WP formulations on rooting of proximal cuttings is illustrated in figure 1D. Distal and proximal cuttings sprouted more abundantly than single node cuttings in summer as well as in winter assays (tables 1 and 2).

Vegetative material excised in spring (October), at the time of flowering and fruit development, did not originate roots in any type of cutting or IBA formulation (results not in tables).

Rooting of juvenile stem cuttings. Rooting started after approximately three weeks of culture. Cuttings excised from juvenile plants exhibited root formation and sprouting in all treatments (table 3). Aqueous solution of IBA (50 $\mathrm{mg} \mathrm{L}^{-1}$ ) displayed the best response with $85 \%$ of rooted explants, followed by Seradix (IBA $0.3 \%$ ) with $72 \%$ of rooted explants (table 3 ). Root number (7.3 roots per explant) was significantly superior in the Seradix treatment and sprouts were healthy, as well as in the $50 \mathrm{mg} \mathrm{L}^{-1}$ IBA treatment (figure 1C). Water alone induced roots in $64 \%$ of the explants and generated vigorous plants as well. The use of lanolin as a carrier for IBA significantly inhibited root formation, root number and length. Sprouting was also reduced by this treatment. Browning and necrosis occurred at the base of the cuttings and residues of lanolin were still present at the end of the culture period. 
Table 1. Rooting responses of adult Guindilia trinervis distal, proximal and single node cuttings harvested in summer from field plants and treated with IBA in solution $\left(\mathrm{mg} \mathrm{L}^{-1}\right)$ or WP $(\%){ }^{(1)}$

Respuestas de enraizamiento de estacas adultas distales, proximales y uninodales de Guindilia trinervis, colectadas en verano y tratadas con soluciones de IBA $\left(\mathrm{mg} \mathrm{L}^{-1}\right)$ o polvo mojable WP $(\%) .^{(1)}$

\begin{tabular}{lccccc}
\hline IBA & $\begin{array}{c}\text { Rooting } \\
(\%)\end{array}$ & $\begin{array}{c}\text { Number of } \\
\text { roots/ } \\
\text { explant }\end{array}$ & $\begin{array}{c}\text { Root } \\
\text { length } \\
(\mathrm{cm})\end{array}$ & $\begin{array}{c}\text { Explants } \\
\text { with } \\
\text { callus (\%) }\end{array}$ & $\begin{array}{c}\text { Axillary } \\
\text { bud } \\
\text { sprouting } \\
(\%)\end{array}$ \\
\hline Distal cuttings & & & & & \\
\hline $0 \mathrm{mg} \mathrm{L}^{-1}$ & $69.0 \mathrm{a}^{(2)}$ & 5.0 & 4.6 & 0.0 & 81 \\
$100 \mathrm{mg} \mathrm{L}^{-1}$ & $79.2 \mathrm{a}$ & 4.7 & 5.8 & 20.0 & 98 \\
$200 \mathrm{mg} \mathrm{L}^{-1}$ & $\mathrm{nd}^{(3)}$ & $\mathrm{nd}$ & $\mathrm{nd}$ & $\mathrm{nd}$ & $\mathrm{nd}$ \\
$400 \mathrm{mg} \mathrm{L}^{-1}$ & $49.6 \mathrm{c}$ & 3.5 & 4.5 & 41.2 & 50 \\
$800 \mathrm{mg} \mathrm{L}^{-1}$ & $63.3 \mathrm{~b}$ & 6.3 & 5.0 & 67.5 & 64 \\
$1,200 \mathrm{mg} \mathrm{L}^{-1}$ & $54.4 \mathrm{bc}$ & 5.9 & 4.1 & 59.7 & 48 \\
$0.2 \%$ & $57.6 \mathrm{~b}$ & 6.3 & 4.7 & 59.3 & 55 \\
$0.4 \%$ & $28.6 \mathrm{~d}$ & 5.8 & 2.4 & 37.0 & 31 \\
$0.8 \%$ & $23.5 \mathrm{~d}$ & 10.8 & 2.9 & 21.8 & 10 \\
$1.2 \%$ & $74.2 \mathrm{a}$ & 13.5 & 2.9 & 70.8 & 48
\end{tabular}

Proximal cuttings

\begin{tabular}{rlllll}
\hline $0 \mathrm{mg} \mathrm{L}^{-1}$ & $57.3 \mathrm{a}$ & 3.3 & 3.4 & 70.1 & 82 \\
$100 \mathrm{mg} \mathrm{L}^{-1}$ & $41.7 \mathrm{~b}$ & 3.6 & 6.1 & 19.2 & 94 \\
$200 \mathrm{mg} \mathrm{L}^{-1}$ & $42.0 \mathrm{~b}$ & 4.2 & 7.5 & 25.2 & 90 \\
$400 \mathrm{mg} \mathrm{L}^{-1}$ & $52.5 \mathrm{a}$ & 5.5 & 5.2 & 28.3 & 98 \\
$800 \mathrm{mg} \mathrm{L}^{-1}$ & $42.9 \mathrm{a}$ & 4.9 & 4.1 & 28.6 & 83 \\
$1,200 \mathrm{mg} \mathrm{L}^{-1}$ & $60.2 \mathrm{a}$ & 7.4 & 4.4 & 67.8 & 91 \\
$0.2 \%$ & $52.3 \mathrm{a}$ & 8.5 & 2.9 & 47.7 & 96 \\
$0.4 \%$ & $19.3 \mathrm{c}$ & 6.2 & 3.1 & 18.5 & 38 \\
$0.8 \%$ & $12.0 \mathrm{c}$ & 8.8 & 3.9 & 12.8 & 13 \\
$1.2 \%$ & $14.2 \mathrm{c}$ & 7.9 & 1.8 & 13.3 & 19
\end{tabular}

Single node cuttings

\begin{tabular}{rrrrrr}
\hline $0 \mathrm{mg} \mathrm{L}^{-1}$ & $49.6 \mathrm{a}$ & 3.5 & 3.2 & 33.6 & 36 \\
$100 \mathrm{mg} \mathrm{L}^{-1}$ & $6.0 \mathrm{~d}$ & 2.7 & 3.1 & 10.3 & 3 \\
$200 \mathrm{mg} \mathrm{L}^{-1}$ & $35.9 \mathrm{~b}$ & 2.3 & 3.5 & 41.9 & 3 \\
$400 \mathrm{mg} \mathrm{L}^{-1}$ & $21.2 \mathrm{c}$ & 3.0 & 3.8 & 22.0 & 0 \\
$800 \mathrm{mg} \mathrm{L}^{-1}$ & $21.4 \mathrm{c}$ & 2.8 & 2.6 & 14.5 & 1 \\
$1,200 \mathrm{mg} \mathrm{L}^{-1}$ & $16.7 \mathrm{c}$ & 2.6 & 2.1 & 25.8 & 0 \\
$0.2 \%$ & $20.2 \mathrm{c}$ & 2.3 & 2.5 & 30.7 & 0 \\
$0.4 \%$ & $5.1 \mathrm{~d}$ & 3.8 & 2.0 & 8.5 & 0 \\
$0.8 \%$ & $5.0 \mathrm{~d}$ & 2.8 & 1.4 & 8.4 & 0 \\
$1.2 \%$ & $30.5 \mathrm{~b}$ & 2.2 & 1.4 & 39.8 & 0 \\
\hline
\end{tabular}

(1) Values represent the mean of 120 measurements taken in February 2009 after 6 weeks of culture.

(2) $P<0.05$. Letters indicate the levels of the comparison of proportions test, where similar letters indicate that means are statistically equal. The first level is represented by the letter a.

(3) nd: no data.
Table 2. Rooting responses of adult Guindilia trinervis distal, proximal and single node cuttings harvested in winter from field plants and treated with IBA in solution $\left(\mathrm{mg} \mathrm{L}^{-1}\right)$ or WP $(\%)^{(1)}$. Respuestas de enraizamiento de estacas adultas distales, proximales y uninodales de Guindilia trinervis colectadas en invierno y tratadas con soluciones de IBA $\left(\mathrm{mg} \mathrm{L}^{-1}\right)$ o polvo mojable WP $(\%)$. $^{(1)}$

\begin{tabular}{|c|c|c|c|c|c|}
\hline IBA & $\begin{array}{l}\text { Rooting } \\
(\%)\end{array}$ & $\begin{array}{c}\text { Number of } \\
\text { roots/ } \\
\text { explant }\end{array}$ & $\begin{array}{c}\text { Root } \\
\text { length } \\
(\mathrm{cm})\end{array}$ & $\begin{array}{l}\text { Explants } \\
\text { with } \\
\text { callus \% }\end{array}$ & $\begin{array}{l}\text { Axillary } \\
\text { bud } \\
\text { sprouting } \\
(\%)\end{array}$ \\
\hline \multicolumn{6}{|l|}{ Distal cuttings } \\
\hline $0 \mathrm{mg} \mathrm{L}^{-1}$ & $18.5 a b^{(2)}$ & 2.8 & 2.4 & 3.4 & 41.2 \\
\hline $100 \mathrm{mg} \mathrm{L}^{-1}$ & $19.2 \mathrm{ab}$ & 2.1 & 3.0 & 6.7 & 23.3 \\
\hline $200 \mathrm{mg} \mathrm{L}^{-1}$ & $24.2 \mathrm{a}$ & 2.3 & 2.3 & 3.3 & 26.7 \\
\hline $400 \mathrm{mg} \mathrm{L}^{-1}$ & $13.3 b$ & 2.2 & 2.4 & 14.2 & 20.8 \\
\hline $800 \mathrm{mg} \mathrm{L}^{-1}$ & $4.2 \mathrm{c}$ & 5.8 & 3.0 & 11.7 & 5.8 \\
\hline $1,200 \mathrm{mg} \mathrm{L}^{-1}$ & $3.3 \mathrm{c}$ & 2.3 & 1.3 & 5.8 & 1.7 \\
\hline $0.2 \%$ & $\mathrm{nd}^{(3)}$ & nd & nd & nd & nd \\
\hline $0.4 \%$ & $25.2 \mathrm{a}$ & 3.2 & 1.8 & 34.5 & 17.6 \\
\hline $0.8 \%$ & $20.0 \mathrm{a}$ & 3.0 & 1.6 & 28.3 & 5.0 \\
\hline $1.2 \%$ & $20.0 \mathrm{a}$ & 4.3 & 0.3 & 18.3 & 1.7 \\
\hline \multicolumn{6}{|l|}{ Proximal cuttings } \\
\hline $0 \mathrm{mg} \mathrm{L}^{-1}$ & $0.0 \mathrm{c}$ & 0.0 & 0.0 & 0.0 & 29.2 \\
\hline $100 \mathrm{mg} \mathrm{L}^{-1}$ & $0.8 \mathrm{bc}$ & 2.0 & 2.3 & 2.5 & 19.2 \\
\hline $200 \mathrm{mg} \mathrm{L}^{-1}$ & $0.0 \mathrm{c}$ & 0.0 & 0.0 & 2.5 & 15.8 \\
\hline $400 \mathrm{mg} \mathrm{L}^{-1}$ & $3.3 \mathrm{c}$ & 2.8 & 0.7 & 1.7 & 15.0 \\
\hline $800 \mathrm{mg} \mathrm{L}^{-1}$ & $3.3 \mathrm{c}$ & 2.0 & 2.4 & 3.3 & 11.7 \\
\hline $1,200 \mathrm{mg} \mathrm{L}^{-1}$ & $1.7 \mathrm{c}$ & 2.0 & 1.5 & 3.3 & 16.7 \\
\hline $0.2 \%$ & $12.3 \mathrm{c}$ & 2.1 & 0.7 & 26.4 & 23.6 \\
\hline $0.4 \%$ & $15.8 \mathrm{a}$ & 2.2 & 1.3 & 18.3 & 10.8 \\
\hline $0.8 \%$ & $10.8 \mathrm{a}$ & 2.5 & 1.3 & 9.2 & 5.0 \\
\hline $1.2 \%$ & $0.0 \mathrm{c}$ & 0.0 & 0.0 & 1.7 & 1.7 \\
\hline
\end{tabular}

Single node cuttings

\begin{tabular}{rccccc}
$0 \mathrm{mg} \mathrm{L}^{-1}$ & $15.5 \mathrm{ab}$ & 1.6 & 3.3 & 0.0 & 6.0 \\
$100 \mathrm{mg} \mathrm{L}^{-1}$ & $1.7 \mathrm{c}$ & 1.0 & 2.4 & 1.7 & 1.7 \\
$200 \mathrm{mg} \mathrm{L}^{-1}$ & $1.7 \mathrm{c}$ & 1.0 & 2.2 & 8.3 & 0.8 \\
$400 \mathrm{mg} \mathrm{L}^{-1}$ & $3.3 \mathrm{c}$ & 1.5 & 1.6 & 1.7 & 0.0 \\
$800 \mathrm{mg} \mathrm{L}^{-1}$ & $19.5 \mathrm{ab}$ & 1.5 & 3.1 & 13.6 & 0.8 \\
$1,200 \mathrm{mg} \mathrm{L}^{-1}$ & $24.6 \mathrm{a}$ & 1.9 & 2.4 & 19.5 & 0.0 \\
$0.2 \%$ & $16.0 \mathrm{ab}$ & 1.6 & 1.7 & 17.6 & 1.7 \\
$0.4 \%$ & $13.6 \mathrm{~b}$ & 3.8 & 1.7 & 17.8 & 0.0 \\
$0.8 \%$ & $14.2 \mathrm{~b}$ & 3.8 & 1.4 & 16.7 & 0.0 \\
$1.2 \%$ & $15.0 \mathrm{ab}$ & 3.7 & 1.9 & 13.3 & 0.8 \\
\hline
\end{tabular}

(1) Values represent the mean of 120 measurements taken in June 2009 after 8 weeks of culture.

(2) $P<0.05$. Letters indicate the levels of the comparison of proportions test, where similar letters indicate that means are statistically equal. The first level is represented by the letter a.

(3) nd: no data. 
Table 3. Rooting responses of juvenile Guindilia trinervis single node cuttings treated with IBA in different formulations. ${ }^{(1)}$

Respuestas de enraizamiento de estacas juveniles uninodales de Guindilia trinervis tratadas con IBA en diferentes formulaciones. ${ }^{(1)}$

\begin{tabular}{lcccc}
\hline $\begin{array}{l}\text { Treatment } \\
\text { IBA }\end{array}$ & $\begin{array}{c}\text { Rooting } \\
(\%)\end{array}$ & $\begin{array}{c}\text { Root } \\
\text { number }\end{array}$ & $\begin{array}{c}\text { Root } \\
\text { length } \\
(\mathrm{cm})\end{array}$ & $\begin{array}{c}\text { Sprouts/ } \\
\text { explant } \\
\text { number }\end{array}$ \\
\hline Water control & $64 \mathrm{~b}^{(2)}$ & $3.6 \mathrm{~b}$ & 4.9 & 1.8 \\
Seradix 0.3\% IBA & $72 \mathrm{ab}$ & $7.3 \mathrm{a}$ & 6.0 & 2.8 \\
Solution 50 mg L-1 IBA & $85 \mathrm{a}$ & $4.6 \mathrm{~b}$ & 6.6 & 2.5 \\
$0.5 \mathrm{mg} \mathrm{IBA} \mathrm{g}{ }^{-1}$ lanolin & $10 \mathrm{c}$ & $0.2 \mathrm{c}$ & 2.5 & 0.1 \\
\hline
\end{tabular}

(1) Values represent the mean of 72 measurements taken in July 2008 after 6 weeks of culture.

(2) $P<0.05$. Letters indicate the levels of the comparison of proportions test, where similar letters indicate that means are statistically equal. The first level is represented by the letter a.
Rooting of in vitro shoot-tip and nodal cultures. Nearly $70 \%$ of the shoot-tips initiated roots at their base (table 4 , figure $1 \mathrm{E}$ ) when cultivated in $1 / 2$ strength MS (T1) and $1 / 4$ strength MS (T3) media, enriched with $1.0 \mathrm{mg} \mathrm{L}^{-1}$ IBA and 10 and $5.0 \mathrm{~g} \mathrm{~L}^{-1}$ of sucrose, respectively. Surprisingly, the combination of $1 / 2$ strength nutrients and $5.0 \mathrm{~g} \mathrm{~L}^{-1}$ sucrose (T2) presented significantly less rooting (25\%), suggesting that efficient rhizogenesis in vitro requires a specific nutrient/sucrose balance. Opposite to the results of ex vitro cuttings, sub-apical nodal sections did not root in any treatment, except when excised from in vitro grown plantlets and transferred to fresh medium. Callus formation reached $91 \%$ in these explants and tended to suffocate shoot growth and root expansion. Browning and necrosis of shoots occurred if culture was sustained. Nevertheless, rooted plantlets that where acclimated as soon as root and shoot growth was evident, were completely viable and adjusted well to greenhouse conditions.

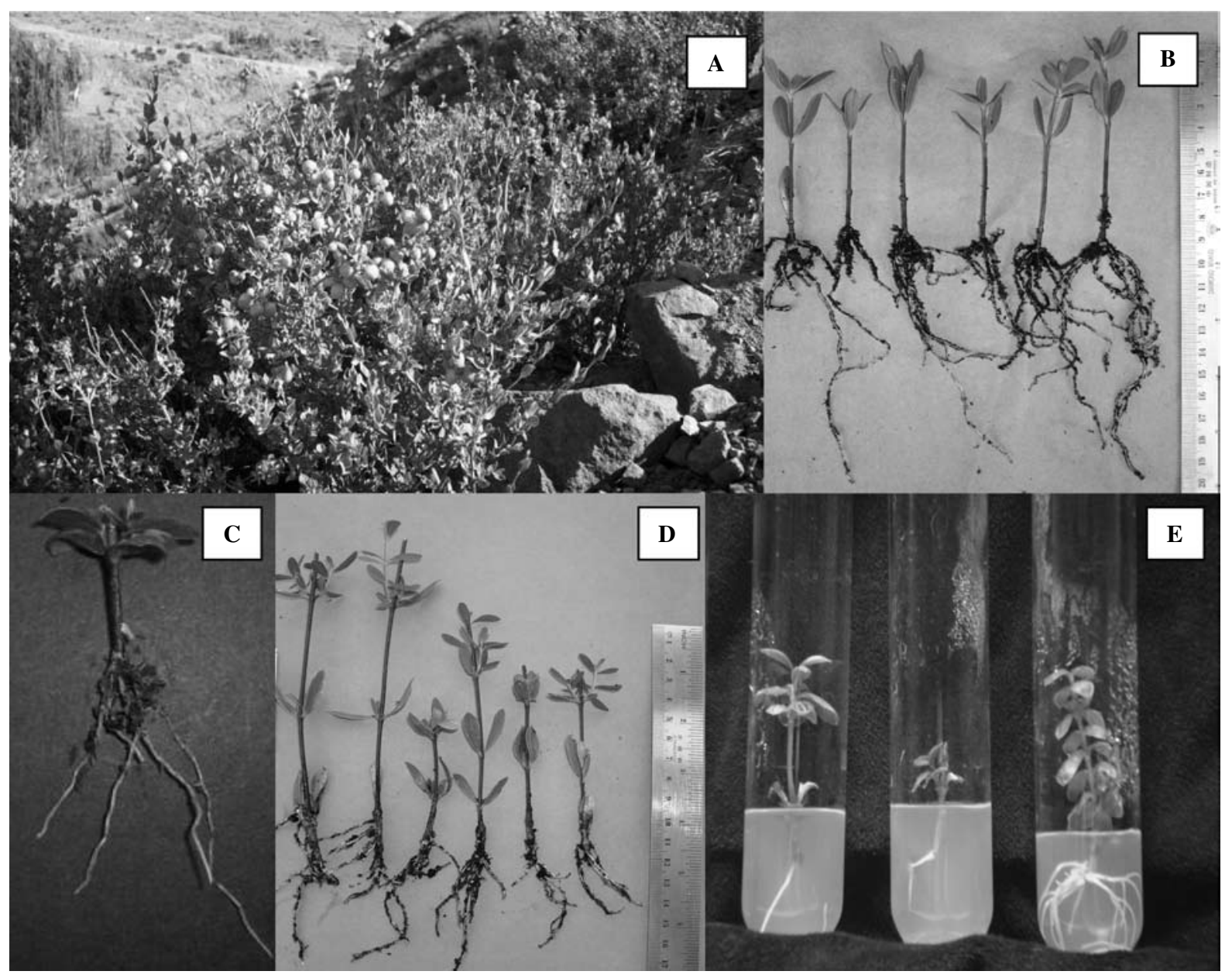

Figure 1. A) Guindilia trinervis in its natural habitat, in flowering, fructification. Eastern slope. B) Polynodal adult cuttings distal position (upper), rooting without IBA. C) Single node juvenile cutting, intermediate position on the branch rooting with $50 \mathrm{mg}$ $\mathrm{L}^{-1}$ IBA. D) Polynodal cuttings, proximal (base) position rooting in $0.2 \%$ IBA in WP and sprouting of axillary buds. E) Caulinary apexes rooting in vitro in presence of $1.0 \mathrm{mg} \mathrm{L}^{-1} \mathrm{IBA}$.

A) Guindilia trinervis en floración y fructificación en su hábitat natural-ladera oriente. B) Estacas distales adultas, enraizadas sin IBA (control). C) Estacas uninodales juveniles, en posición intermedia sobre la rama, enraizadas con $50 \mathrm{mg} \mathrm{L}^{-1}$ IBA. D) Estacas polinodales proximales adultas, enraizadas con 0,2\% IBA WP, con brotación de yemas axilares. E) Ápices caulinares enraizando in vitro en presencia de $1 \mathrm{mg} \mathrm{\textrm {L } ^ { - 1 }}$ de IBA. 
Table 4. In vitro rooting responses of shoot-tips and sub-apical nodal segments of Guindilia trinervis cultured in modified MS medium supplemented with $1.0 \mathrm{mg} \mathrm{L}^{-1}$ IBA. ${ }^{(1)}$

Respuestas de enraizamiento in vitro de ápices y segmentos nodales de Guindilia trinervis cultivadas en medio MS modificado y suplementado con $1,0 \mathrm{mg} \mathrm{L}^{-1}$ IBA. $^{(1)}$

\begin{tabular}{|c|c|c|c|c|c|}
\hline Medium & Explant type & (n) & $\begin{array}{c}\text { Rooting } \\
(\%)\end{array}$ & $\begin{array}{c}\text { Average } \mathrm{N}^{\circ} \\
\text { roots/explant }\end{array}$ & $\begin{array}{c}\text { Callus } \\
(\%)\end{array}$ \\
\hline \multirow[t]{4}{*}{$\mathrm{T} 1$} & Shoot tip ${ }^{(1)}$ & 29 & $72 a^{(3)}$ & 3.8 & 40 \\
\hline & Nodal section ${ }^{(1)}$ & 5 & 0 & 0 & 0 \\
\hline & Shoot tip ${ }^{(2)}$ & 24 & $82 a$ & 6.2 & 25 \\
\hline & Nodal section ${ }^{(2)}$ & 42 & 0 & 0 & 0 \\
\hline \multirow[t]{2}{*}{$\mathrm{T} 2$} & Shoot tip ${ }^{(1)}$ & 33 & $25 b$ & 2.9 & 50 \\
\hline & Nodal section $^{(1)}$ & $\mathrm{nd}^{(4)}$ & nd & nd & nd \\
\hline \multirow[t]{2}{*}{$\mathrm{T} 3$} & Shoot tip ${ }^{(1)}$ & 54 & $70 \mathrm{a}$ & 4.5 & 68 \\
\hline & Nodal section $^{(1)}$ & 49 & 55 & 3.0 & 91 \\
\hline
\end{tabular}

(1) Numbers represent mean values of measurements taken after 4 weeks of in vitro culture.

(2) Shoot tips and Nodal section derived from in vitro plantlets.

(3) $\quad P<0.05$. Letters indicate the levels of the comparison of proportions test, where similar letters indicate that means are statistically equal. The first level is represented by the letter a.

(4) nd: no data.

\section{DISCUSSION}

Guindilia trinervis can massively be reproduced asexually by cuttings from wild plants. Distal polynodal cuttings from adult plants harvested in late summer display the best rooting. After 6-8 weeks of culture in proper substrate and greenhouse conditions, rooting is achieved in the presence of IBA as well as with water alone. Cuttings from juvenile plants also root in presence or absence of IBA but the effect is strongly inhibited when IBA is applied in combination with lanolin. This lack of response may be associated with inhibition of cambial activity by lanolin. Sundberg and Little (1990) reported inhibition of cambial reactivation for rebudded cuttings of Pinus sylvestris L. treated with plain lanolin, but not with lanolin supplemented with auxin. Berry and Sargent (2009) demonstrated that lanolin also reduces the availability of oxygen. In our observations G. trinervis is especially susceptible to hypoxia. On the wild it grows on well drained soils and during greenhouse culture, excessive irrigation causes chlorosis and spontaneous death of plants. Previous results in our research (unpublished) showed that an adequate supply of oxygen may be the limiting factor for root development and seedling germination.

In vitro rooting of apical shoots from young plants is effective as well. This method, although not cost effective compared to ex vitro rooting, is a valuable tool for further research on micropropagation given that the species is prone to callus formation in tissue culture.
Future breeding strategies that require biotechnological tools will require efficient regeneration protocols to foster plant improvement.

Rooting of the different types of cuttings assayed showed a seasonal response; at the entrance of winter rhizogenesis was strongly reduced. This response can be explained since plants enter an intense vegetative recess and adjust metabolically to halt growth due to the low winter temperatures, especially at high elevations in the sub Andean ecosystems. It is known that limited growth response is related to low endogenous auxin availability and/or synthesis during the cold season, particularly in proximal cuttings that exhibit a greater degree of recess. Better rooting responses in winter observed in IBA powder (WP) may be explained by a more stable and or long-term auxin availability in this formulation. Furthermore, consistent with an increase of endogenous hormone levels during the summer and probably related to the size of distal or proximal explants, axillary bud sprouting was more intense than sprouting observed in single node cuttings.

Vegetative material excised in spring (October), at the time of flowering and fruit development, did not originate roots in any type of cutting or IBA formulation. This effect may be attributed to reallocation of nutrients and plant growth regulators at a moment when the metabolism is centered on flower and fruit development.

Propagation of $G$. trinervis by seeds is also feasible. Preliminary results, based on the production of juvenile plants for our experiments, indicate that annual seeds, as well as seeds kept in proper conditions for a second year, retain nearly $95 \%$ viability, and germination succeeds to a similar extent ${ }^{3}$. The first flowering/fruit set has been reported to occur after the third year (Riedemann and Aldunate 2004) when the plant reaches sexual maturity. The presence of seeds is helpful in detecting and selecting elite plants with useful traits as no other selection has worked and only scarce phenotypic characterization of this species has been completed so far. Some characterization of oil content in seeds of various selections from different locations is taking place now ${ }^{4}$. Preliminary selections considering these or other traits will help to increase germplasm stocks to install the species as an alternative crop for oil production in marginal, uncultivated areas. Therefore, an efficient method to asexually propagate this plant material is considered necessary. According to groundwork results it appears that the species, as others from the Sapindaceae family (Litz 1988, Closs 2002, Goren and Gazit 2005, Thomas and Maseena 2006, Soundy et al. 2008, Jahan and Anis 2009), can achieve root regeneration easily and yield plant material for massive propagation in vivo and

3 Gloria Margot Parada. Laboratorio de Bioingeniería, Facultad de Ingeniería y Ciencias, Universidad Adolfo Ibáñez. Personal communication.

4 Ricardo San Martín. Pontificia Universidad Católica de Chile. Personal communication. 
in vitro. The survival of donor plants in the unique sub Andean ecosystem should not be a crucial concern for programs concerned about the reclamation of the shrub. Guindilia trinervis may become an interesting alternative for biodiesel production in Mediterranean areas if the plant can adapt its growth to lower altitudes and oil yield is increased. We are currently studying its performance in response to nitrogen and phosphor levels in the soil as well as floral biology at lower elevations.

\section{CONCLUSIONS}

Guindilia trinervis is an easy-to-root species. Distal polynodal cuttings are the most amenable material for asexual reproduction of field plants. Exogenous application of IBA is not required to obtain successful rooting of adult or juvenile material. Cuttings retain their ability to root in late summer and winter, but not during flowering and fructification. In vitro rooting of apical shoots can also be achieved but micropropagation requires further investigation.

\section{ACKNOWLEDGEMENTS}

The Curator of the Natural History Museum of Santiago, Dr. M. Muñoz provided the species' taxonomic data and Mme. Andrée Goreux revised the manuscript. This work was supported by Fondecyt Grant Nr. 1080117 to Prof. Dr. R. San Martín and Fidum Grant. Univ. Mayor to Profs. J. Velozo and M. Jordan.

\section{REFERENCES}

Aguilera JM, A Fretes, R San Martín. 1986. Characteristics of guindilla (Valenzuela trinervis Bert.) oil. Journal of the American Oil Chemists Society 63(12): 1568-1571.

Ahuja MR, WJ Libby. 1993. Clonal Forestry I. Springer-Verlag, Berlin \& Heidelberg, Germany, 277 p.

Bawa K. 1977. The reproductive biology of Cupania guatemaltensis Radlk (Sapindaceae). Evolution 3(1): 52-53.

Berry AD, SA Sargent. 2009. Real-time microsensor measurement of internal oxygen partial pressure in tomato fruit under hypoxic conditions. Postharvest Biology and Technology 52(2): 240-242.

Closs J. 2002. Dodonaea-The hop bush. Australian plants online. Australia. Australian plants online-September 2002. Consulted January 12, 2010. Available at http://asgap.org. au/APOL27/sep02-1.html

Ferrucci MS. 1998. Sapindaceae. In Hunziker AT ed. Flora Fanerogámica Argentina 52: 1-44. Córdoba, Argentina.

Goren M, S Gazit. 2005. Rooting of lychee and longan cuttings under mist-A commercial effective method. In Chomchalow M. and N Sukhvibul eds. II International Symposium on
Lychee, Longan, Rambutan and other Sapindaceae Plants. Acta Horticulturae 665: 297-300.

Hartmann HT, DE Kester, FT Davies, RL Geneve. 2001. Hartmann and Kester's Plant propagation: Principles and practices. Englewood Cliffs, NJ. Prentice Hall. 880 p.

Hoffmann A. 1998. Flora silvestre de Chile, Zona Central. Edición 4. Santiago, Chile. Fundación Claudio Gay. 254 p.

Iglesias R, E Taha. 2010. Monografías de especies anuales, arbustivas y acuícolas con potencial energético en Chile. Oficina de Estudios y Políticas Agrarias (ODEPA), Santiago.

Jahan AA, M Anis. 2009. In vitro rapid multiplication and propagation of Cardiospermum halicacabum L. through axillary bud culture. Acta Physiologiae Plantarum 31: 133-138.

Kohan NC, JM Carro. 1970. Estadística aplicada. Buenos Aires, Argentina. Editorial Universitaria. 368 p.

Litz RE. 1988. Somatic embryogenesis from cultured leaf explants of the tropical tree Euphoria longan Stend. Journal of Plant Physiology 132: 190-193.

Muñoz M, A Moreira-Muñoz, C Villagrán, F Luebert. 2000. Caracterización florística y pisos de vegetación en los Andes de Santiago, Chile Central. Boletín del Museo Nacional de Historia Natural, Chile 49: 9-50.

Muñoz A, MT Arroyo. 2006. Pollen limitation and spatial variation of reproductive success in the insect pollinated shrub Chuquiraga oppositifolia (Asteraceae) in the Chilean Andes. Arctic, Antarctic, and Alpine Research 38(4): 608-613.

Murashige T, F Skoog. 1962. A revised medium for rapid growth and bioassays with tobacco tissue cultures. Plant Physiol. 15: 473-497.

Riedemann P, G Aldunate. 2004. Flora nativa de valor ornamental; Identificación y propagación. Chile, Zona Centro. Edición 2. Santiago, Chile. Andrés Bello. 566 p.

Riedemann P, G Aldunate, S Teillier. 2008. Flora nativa de valor ornamental; Identificación y propagación. Chile, Zona Cordillera de Los Andes. Santiago, Chile. Ediciones Chagual. 674 p.

Seigler DS, M Cortés, JM Aguilera. 1987. Chemical components of guindilla seeds (Valenzuelia trinervis). Biochemical Systematics and Ecology 15: 71-73.

Soundy P, KW Mpati, ES du Toit, FN Mudau, HT Araya. 2008. Influence of cutting position, medium, hormone and season on rooting of fever tea (Lippia javanica L.) stem cuttings. Medicinal and Aromatic Plant Science and Biotechnology 2: 114-116.

Sundberg B, A. Little. 1990. Tracheid production in response to changes in the internal level of indole-3-acetic acid in 1-year-old shoots of scots pine. Plant Physiol. 94(4): 17211727.

Teillier S, G Aldunate, P Riedemann, H Niemeyer. 2005. Flora de la Reserva Nacional Río Clarillo. Santiago, Chile. Impresos Socías Ltda. 367 p.

Thomas TD, EA Maseena. 2006. Callus induction and plant regeneration in Cardiospermum halicacabum Linn. an important medicinal plant. Scientia Horticulturae 108: 332-336.

Recibido: 27.01 .10

Aceptado: 24.06 .10 